\title{
Continuance Intention Customer Analysis On Online Accounting Software Usage
}

\author{
Zulfati Imani Syamsu, Mohamad Rizan, Budi Santoso \\ State University of Jakarta, Jakarta Indonesia \\ State University of Jakarta, Jakarta Indonesia \\ State University of Jakarta, Jakarta Indonesia \\ Email: imanizulfati@ymail.com
}

\section{ARTICLE INFO}

Date received : 20 September 2020

Revision date : : 28 October 2020

Date received :19 November 2020

\section{Keywords:}

perceived usefulness

information quality

system qualit

service quality

satisfaction

continuance intention

\begin{abstract}
Software as a Service (SaaS) is a variant of technology products that are now loved by both personal and business users. SaaS is a software product variant that can be used directly by users, without the need for complicated installation. In the realm of accounting itself, there have been many emerging accounting softwares ranging from those that are offline to online, one of which is Jurnal.id. Jurnal.id is a SaaS platform that presents a variety of digital accounting products that are designed to simplify and accelerate the process of bookkeeping business. This study aims to examine customer continuance intentions on the use of Jurnal.id online accounting software. The variables in this study consisted of perceived usefulness, information quality, service quality system quality, satisfaction, and continuance intention. The population in this study are the users of Jurnal.id Online Accounting Software in the Greater Jakarta area. The sample in this study amounted to 300 people obtained using the Hair Formula. This study uses the Structural Equation Model (SEM) approach using Partial Least Square (PLS) software, the SMART-PLS software version 3.3.2. The results showed that perceived usefulness, system quality, and service quality had a positive effect on satisfaction using Jurnal.id's online accounting software. Simultaneously Satisfaction has a positive effect on continuance intention. However, Information quality does not have a positive effect on satisfaction using online accounting software Jurnal.id.
\end{abstract}

\section{INTRODUCTION}

Advances in technology, computers and telecommunications support the development of internet technology. The Internet is a global forum for modern humans to exchange information and become a source of information. The internet has created a new economic world that has an impact on several aspects of life, including the development of the business world (Efrilia, 2016). This is an opportunity for IT developers to create applications to facilitate daily productivity activities, including the SaaS platform, seeing that many Indonesians use the internet and have supporting devices.

Software as a Service (SaaS) is a variant of technology products that are now widely loved, both by personal and business users. In Indonesia, there are many digital startup companies that develop SaaS type products. Examples of popular SaaS applications in Indonesia are Gojek and Grab for online motorcycle taxis and taxis, Moka Pos for online cashiers, Tokopedia and Shopee for the online marketplace, Talenta for HRD software, and Zoho for CRM. In the realm of accounting itself, many accounting software has appeared, ranging from offline (desktop) to online based, one of which is Jurnal.id.

Based on primary data obtained by researchers, during the last 4 years there has been a significant growth in terms of the number of users each year. Of the total users who register or trial, only about $10 \%$ of the total registered users finally decide to make Jurnal.id payments. Meanwhile, of the number of users who have made the first payment, only about $40 \%$ will continue to pay the subscription fee the following month. This amount is very small when compared to the total customers who have made payments. From this it can be seen that not all Journal.id users who have made 
payments intend to continue using the Journal.id software.

Continuous usage intention is very important because the longer a company or business can retain customers, the greater the life-time revenue from these customers and at the same time can reduce customer service costs (Mittal \& Lassar, 1998). In addition, the high intention of continued use also reflects that the program or product is well designed and implemented (Rinaldi \& Santoso, 2018).

$\mathrm{Ha}$ and Park (2013) said that one of the main determinants of Continuance Intention to use a system is customer satisfaction. In the IS field, user satisfaction with technology is also an important factor influencing the adoption and sustainable use of a technology (Bhattacherjee, 2001). The Information System Success Model (IS Success Model) developed by Delone \& McLean (1992) provides a comprehensive understanding of the success of an information system. The development of this theory is carried out by identifying and describing the relationship between information quality, system quality, and service quality on customer satisfaction and how customer satisfaction affects net benefits. Meanwhile, the ExpectationConfirmation Model (ECM) is a research model in the field of information systems developed by (Bhattacherjee, 2001) which measures satisfaction, confirmation, and perceived usefulness as the main causes of intention to continue using information systems.

Based on research conducted by (Islam et al. 2017) regarding Continuance Intention using IT found that perceived usefulness affects satisfaction in using information technology. Widodo et al. (2016) in their research on the effect of system quality and information quality on the satisfaction of the RTS (Rail Ticketing System) application system also shows that information quality affects satisfaction. Meanwhile, (Ahmed \& Ali, 2017) conducted a study on consumers' continuous intention on Mobile Money Transfers, also showing that system quality affects satisfaction. Research from (Kim et al. 2017) regarding continuance intention of using mobile travel information services (MTIS) also show that service quality affects satisfaction. In addition, (Koloseni \& Mandari, 2017) in their research on the factors that influence the continued use of online money services shows that Satisfaction has an effect on Continuance Intention.

\section{THEORITICAL FRAMEWORK AND HYPOTHESIS}

\section{The Effect of Perceived Usefulness on} Satisfaction

According to (Venkatesh \& Davis, 2000), Perceived Usefulness or perceived benefits is defined as the extent to which a person believes that using a technology will improve one's performance.
According to (Kotler \& Keller, 2009), customer satisfaction is a person's assessment of product performance that comes after comparing the perceived performance / results with expectations. If the product's performance does not meet expectations, then the customer is dissatisfied and disappointed. If the product meets expectations, the customer is satisfied. If the product's performance exceeds expectations, the customer will be very happy. Research from (Bölen \& Özen, 2020) regarding continuance intention to use online shopping sites shows that perceived usefulness has a positive effect on satisfaction. Based on this description, the following research hypothesis is formulated:

\section{H1: Perceived usefulness has a positive effect on satisfaction}

\section{The Effect Of Information Quality On Satisfaction}

DeLone \& McLean (1992) define information quality as referring to the quality of information that can be stored, sent, or produced by the system, and is one of the most common dimensions in which information systems are evaluated. (Bhattacherjee, 2001) formulates satisfaction as the influence or feelings of consumers on the use of a system. (Widodo et al. 2016) in their research on the effect of system quality and information quality on the satisfaction of the RTS (Rail Ticketing System) application system also shows that information quality has a positive effect on satisfaction. Based on this description, the following research hypothesis is formulated:

\section{H2: Information quality has a positive effect on satisfaction}

\section{The Effect of System Quality on Satisfaction}

According to (Gaspersz, 2008) system quality is a set of documented procedures and standard practices for system management that aim to ensure the conformity of a process and product (goods or services) to the needs of certain requirements determined by customers and organizations. The quality of the system is measured subjectively by the user, so that the quality of the system used is the perceived system quality. The quality of the system indirectly impacts the extent to which the system is able to provide benefits through a mediational relationship through the use intention and user satisfaction constructs (Eriksson \& Törn, 1997). Research from (Hudin \& Riana, 2016) regarding the factors that measure the success of DeLone \& McLean's information system success model for Accurate accounting software users shows that system quality has a positive effect on satisfaction. Based on this description, the following research hypothesis is formulated: 


\section{H3: System quality has a positive effect on satisfaction}

\section{The Effect of Service Quality on Satisfaction}

(Wyckoff, 1984) states that the notion of service quality is the level of expected perfection and control over that perfection to fulfill customer desires. According to (Zeithaml et al. 2010), satisfaction is the response or user responses regarding meeting needs. Customer satisfaction is an assessment of the characteristics or features of a product or service, or the product itself, which provides a level of enjoyment related to meeting customer needs, customer satisfaction can be assessed through quality, service and value. (Nuraini \& Mudiantono's research, 2017) regarding the factors that affect customer satisfaction and their impact on the repurchase intention of the Traveloka site also shows that service quality has a positive effect on satisfaction. Based on this description, the following research hypothesis is formulated:

\section{H4: Service quality has a positive effect on satisfaction}

\section{The Effect of Satisfaction on Continuance Intention}

Satisfaction according to (Yamit, 2013) is the perceived result of the use of products and services, equal to or exceeding the desired expectations. According to (Bhattacherjee, 2001), continuance intention is defined as an interest in continuing to participate or take part in a particular system. The success of an information system depends on the continued use of the initial use, because when someone starts using an information system, one's psychological motivation will influence the decision to continue using the information system. Based on research conducted by (Ifinedo, 2018) regarding Continuance Intention using Weblogs shows that Satisfaction affects customer Continuance Intention Based on the description, the research hypothesis is formulated as follows:

H5: satisfaction has a positive effect on continuance intention

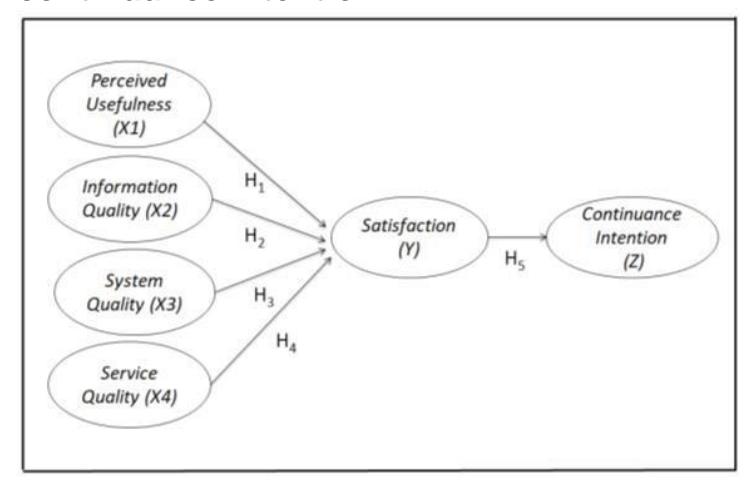

\section{METODE}

The type of research used in this research is causal-associative with a quantitative approach. In addition, for data collection using survey techniques. The collection was carried out by distributing questionnaires and interviews to several existing Jurnal.id clients. The data analysis technique was carried out using a Structural Equation Model (SEM) approach using Partial Least Square (PLS) software, namely the SMART-PLS version 3.3.2 software.

\section{Population and Sample}

The population in this study were all users of the Journal.id Online Accounting Software in the Jabodetabek area. The sample size was taken using the Hair Formula and the sample in this study was 300 people. The sampling technique used in this study is nonprobability sampling. The nonprobability sampling technique used in sampling in this study is convenience sampling.

\section{Variables and Indicators}

The variables in this study consisted of independent variables (independent) and dependent variables (dependent). The independent variables in this study are Perceived Usefulness (X1), Information Quality (X2), System Quality (X3), Service Quality (X4), Satisfaction (Y). While the dependent variable used in this study is Continuance Intention (Z).

\section{RESULTS AND DISCUSSION}

\section{Testing the Measurement Model (Outer Model)}

Evaluation of the measurement model is used to evaluate the relationship between the construct and its indicators through validity tests (convergent validity and discriminant validity) and reliability tests (construct reliability). The results of the evaluation of the measurement model in the initial stages are shown in the Figure below. 


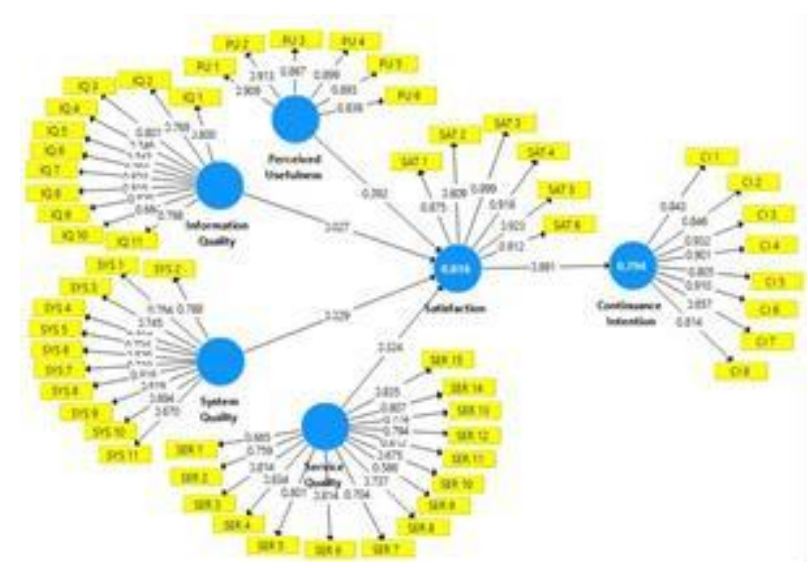

Figure 2. Outer Loading Model

After evaluating the measurement model, the next step is to evaluate the structural model. The structural model evaluation was carried out through the bootstrap method with a resampling amount of 5000 for one-tailed testing. The bootstrapping results on the evaluation of the structural model can be seen in the figure below.

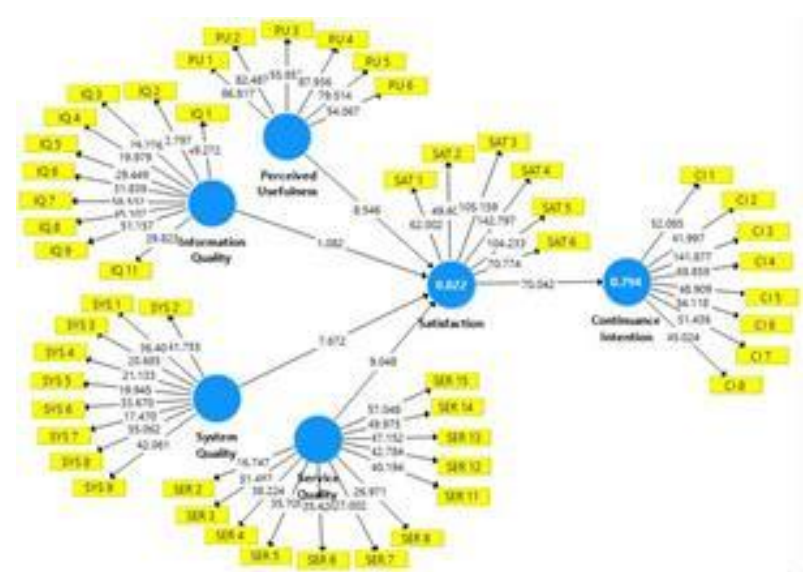

Figure 3. Bootstrapping Structural Model Result

\section{Hypothesis Testing}

Hypothesis testing is carried out at the structural model evaluation stage through path coefficient analysis, through the t-statistical value test and $p$-value on the one-tailed hypothesis test with a significance value used t-value 1.650 (significance level $=5 \%$ ) (Ghozali \& Latan, 2015). The results of hypothesis testing in this study are summarized in the table below.

Table 1. Hypothesis Test Results

\begin{tabular}{|c|c|c|c|c|c|c|}
\hline \multicolumn{2}{|c|}{ Hypothesis } & $\begin{array}{c}\text { Origin } \\
\text { al } \\
\text { Sampl }\end{array}$ & $\begin{array}{c}T \\
\text { Statistic }\end{array}$ & $\begin{array}{c}P \\
\text { Value }\end{array}$ & Effect & Result \\
\hline $\mathrm{H} 1$ & $\begin{array}{l}\text { Perceive } \\
d \\
\text { Usefulne } \\
\text { ss } \rightarrow \\
\text { Satisfacti } \\
\text { on }\end{array}$ & 0,369 & 8,546 & 0,000 & $\begin{array}{l}\text { Significa } \\
\text { nt } \\
\text { Positive }\end{array}$ & $\begin{array}{l}\text { Hypothes } \\
\text { is } \\
\text { accepted }\end{array}$ \\
\hline $\mathrm{H} 2$ & $\begin{array}{l}\text { Informati } \\
\text { on } \\
\text { Quality } \\
\overrightarrow{\text { Satisfacti }}\end{array}$ & 0,061 & 1,082 & 0,140 & $\begin{array}{l}\text { Not } \\
\text { Significa } \\
\text { nt }\end{array}$ & $\begin{array}{l}\text { Hypothes } \\
\text { is } \\
\text { rejected }\end{array}$ \\
\hline
\end{tabular}

\begin{tabular}{|c|c|c|c|c|c|c|}
\hline & on & & & & & \\
\hline H3 & $\begin{array}{l}\text { System } \\
\text { Quality } \\
\rightarrow \\
\text { Satisfacti } \\
\text { on }\end{array}$ & 0,209 & 7,672 & 0,000 & $\begin{array}{l}\text { Significa } \\
\text { nt } \\
\text { Positive }\end{array}$ & $\begin{array}{l}\text { Hypothes } \\
\text { is } \\
\text { accepted }\end{array}$ \\
\hline H4 & $\begin{array}{l}\text { Service } \\
\text { Quality } \\
\rightarrow \\
\text { Satisfacti } \\
\text { on } \\
\end{array}$ & 0,353 & 9,048 & 0,000 & $\begin{array}{l}\text { Significa } \\
\text { nt } \\
\text { Positive }\end{array}$ & $\begin{array}{l}\text { Hypothes } \\
\text { is } \\
\text { accepted }\end{array}$ \\
\hline H5 & $\begin{array}{l}\text { Satisfacti } \\
\text { on } \rightarrow \\
\text { Continua } \\
\text { nce } \\
\text { Intention }\end{array}$ & 0,891 & 70,042 & 0,000 & $\begin{array}{l}\text { Significa } \\
\text { nt } \\
\text { Positive }\end{array}$ & $\begin{array}{l}\text { Hypothes } \\
\text { is } \\
\text { accepted }\end{array}$ \\
\hline
\end{tabular}

Based on the results of hypothesis testing in table $4: 23$ above, it can be seen that of the five hypotheses proposed in this study, four hypotheses are accepted and one hypothesis is not accepted, with details as follows:

1. The results of the $\mathrm{H} 1$ hypothesis test showed a significant positive effect between Perceived Usefullnes on Satisfaction as indicated by the tstatistic value of $8.546>1.650$; The $p$-value is $0.000<0.05$, and the original sample value is positive at 0.369 , thus the $\mathrm{H} 1$ hypothesis is accepted.

2. The results of the $\mathrm{H} 2$ hypothesis test showed that there was no significant positive effect between Information Quality on Satisfaction as indicated by the t-statistic value of 1.082 $<1.650$; $p$-values $0.140>0.05$, and the original sample value is positive at 0.061 , thus the $\mathrm{H} 2$ hypothesis is not accepted.

3. Hypothesis test results $\mathrm{H} 3$ shows a significant positive effect between System Quality on Satisfcation as indicated by the t-statistic value of 7.672> 1.650; the $p$-value is $0.000<0.05$, and the original sample value is positive at 0.209 , thus the hypothesis $\mathrm{H} 3$ is accepted.

4. 4. Hypothesis test results $\mathrm{H} 4$ shows a significant positive effect between Service Quality on Satisfcation as indicated by the tstatistic value $9,048>1,650$; a $p$-value of 0,000 $<0.05$, and a positive original sample value of 0.353 , thus Hypothesis $\mathrm{H} 4$ is accepted.

5. Hypothesis test results $\mathrm{H} 5$ shows a significant positive effect between Satisfaction on Continuance Intention as indicated by the tstatistic value $70.042>1.650 ; p$-values 0.000 $<0.05$, and the original sample value is positive at 0.891 , thus Hypothesis $\mathrm{H} 5$ is accepted.

\section{CONCLUSION}

Based on the data from the research, discussion, and analysis that has been carried out in the previous chapter, the conclusions that can be drawn from research regarding the Continuance Intention of Customer Analysis on the Use of Online Accounting Software are as follows: 
First, Perceived usefulness has a positive effect on satisfaction using Journal.id's online accounting software. With the fulfillment of user expectations for the benefits they get from using Jurnal.id, their satisfaction is also fulfilled at a fairly high level.

Second, Information quality has no positive effect on satisfaction using Journal.id's online accounting software. The high quality of information from Jurnal.id does not necessarily affect the satisfaction of its users.

Third, System Quality has a positive effect on satisfaction using Journal.id's online accounting software. The higher or the better the quality of the journal.id system, the higher the satisfaction of its users.

Fourth, Service quality has a positive effect on satisfaction using Journal.id's online accounting software. Fulfilling the quality of service in accordance with user expectations will create a sense of pleasure and satisfaction for its users.

Fifth, Satisfaction has a positive effect on continuance intention to use online accounting software, Jurnal.id. Thus, the interest of users or customers to continue using Jurnal.id products and services depends on the satisfaction they feel with using these products.

\section{References}

Ahmed, I., \& Ali, A. (2017). Determinants of Continuance Intention to Use Mobile Money Transfer: An Integrated Model. Journal of Internet Banking and Commerce, 22(S7), 124. http://www.icommercecentral.com

Bhattacherjee, A. (2001). Understanding Information Systems Continuance: An ExpectationConfirmation Model. MIS Quarterly, 25(3), 351-370.

Bölen, M. C., \& Özen, Ü. (2020). Understanding the Factors Affecting Consumers' Continuance Intention in Mobile Shopping: The Case of Private Shopping Clubs. International Journal of Mobile Communications, 18(1), 101-129. https://doi.org/10.1504/ijmc.2020.104423

DeLone, W. H., \& McLean, E. R. (1992). Information Systems Success: The Quest for the Dependent Variable. The Institue of Management Sciences, 3(1), 60-95. https://doi.org/10.5267/j.uscm.2014.12.002

Efrilia, S. (2016). Pengaruh Kemudahan Penggunaan E-Commerce Terhadap Keputusan Pembelian Online (Studi Pada Konsumen Tokopedia.Com Di Kota Medan) [Skripsi]. Fakultas IImu Sosial Dan IImu Politik Universitas Sumatera Utara.

Eriksson, I., \& Törn, A. (1997). Introduction to IST Special Issue on Information System Quality. Information and Software Technology, 39(12), 797-799.
https://doi.org/https://doi.org/10.1016/S0950 $-5849(97) 00037-2$

Gaspersz, V. (2008). Total Quality Management TQM Untuk Praktis Bisnis dan Industri. Gramedia Pustaka Utama.

Ghozali, I., \& Latan, H. (2015). Partial Least Square Konsep Teknik dan Aplikasi Menggunakan Program SmartPLS 3.0 (2nd Edition). Badan Penerbit Universitas Diponegoro.

Hudin, J. M., \& Riana, D. (2016). Kajian Model Kesuksesan Sistem Informasi Delone \& Mclean Pada Pengguna Sistem Informasi Akuntansi Accurate Di Kota Sukabumi. Jurnal Sistem Informasi, 12(1), 1-8. https://doi.org/10.21609/jsi.v12i1.444

Ifinedo, P. (2018). Roles of Perceived Fit and Perceived Individual Learning Support in Students' Weblogs Continuance Usage Intention. International Journal of Educational Technology in Higher Education, 15(7), 1-18. https://doi.org/10.1186/s41239-018-0092-3

Islam, A. K. M. N., Mäntymäki, M., \& Bhattacherjee, A. (2017). Towards a Decomposed Expectation Confirmation Model of IT Continuance: The Role of Usability. Communications of the Association for Information Systems, 40(23), 502-523. https://doi.org/10.17705/1cais.04023

Kim, J. Y., Chung, N., \& Ahn, K. M. (2017). The Impact of Mobile Tour Information Services on Destination Travel Intention. Information Development, 20(10), 1-14. https://doi.org/10.1177/0266666917730437

Koloseni, D., \& Mandari, H. (2017). Why Mobile Money Users Keep Increasing? Investigating the Continuance Usage of Mobile Money Services in Tanzania. Journal of International Technology and Information Management, 26(2), 117-143.

Kotler, P., \& Keller, K. L. (2009). Marketing Management (13th ed.). Pearson Education Inc.

Mittal, B., \& Lassar, W. M. (1998). Why do Customers Switch? The Dynamics of Satisfaction Versus Loyalty. Journal of Services Marketing, 12(3), 177-194. https://doi.org/10.1108/0887604981021950 2

Nuraini, I. S., \& Mudiantono. (2017). Faktor-faktor yang Mempengaruhi Kepuasan Pelanggan Serta Dampaknya terhadap Minat Beli Ulang Situs Traveloka (Studi pada Konsumen Traveloka di Kota Semarang). Diponegoro Journal of Management, 6(4), $1-11$.

Rinaldi, A., \& Santoso, S. B. (2018). Analisis Pengaruh Kualitas Informasi, Kualitas Sistem dan Kualitas Pelayanan terhadap Minat Beli Ulang dengan Kepuasan Pelanggan sebagai Variabel Intervening 
(Studi pada Pelanggan Traveloka di Kota Semarang). Diponegoro Journal of Management, $\quad 7(2), \quad$ 1-14. https://ejournal3.undip.ac.id/index.php/djom/ article/view/20901

Venkatesh, V., \& Davis, F. D. (2000). A Theoretical Extension of the Technology Acceptance Model: Four Longitudinal Field Studies. Management Science, 46(2), 186-204. https://doi.org/10.1287/mnsc.46.2.186.1192 6

Widodo, A., Putranti, H. R. D., \& Nurchayati. (2016). Pengaruh Kualitas Sistem Aplikasi dan Kualitas Informasi Terhadap Kepuasan Pengguna Sistem Aplikasi RTS (Rail
Ticketing System). Jurmal Media Ekonomi Dan Manajemen, 31(2), 160-181.

Wyckoff, D. D. (1984). New Tools for Achieving Service Quality. Cornell Hotel and Restaurant Administration Quarterly, 25(3), 78-91.

Yamit, Z. (2013). Manajemen Kualitas Produk \& Jasa. Ekonisia.

Zeithaml, V. A., Bitner, M. J., \& Gremler, D. D. (2010). Services Marketing Strategy. Wiley International Encyclopedia of Marketing, 111.

https://doi.org/10.1002/9781444316568.wie m01055

\section{Copyright holder:}

Zulfati Imani Syamsu, Mohamad Rizan, Budi Santoso (2020)

\section{First publication right:}

Journal of Social Science

This article is licensed under:

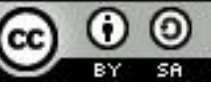

